\title{
Alliances, Open Innovation and Outside-in Management
}

\author{
Elisa Arrigo*
}

\begin{abstract}
Market-driven firms adopt an outside-in management that goes far beyond a simple observation of competitors and understanding of customers' needs, in order to grasp new market opportunities. In this sense, strategic alliances have become increasingly important to the firms' external knowledge access and innovation; firms enter into global networks to share both knowledge and costs and to increase their innovativeness. In this way, as shown in the Philips case, being open to the outside, market-driven firms expand their innovation potential and open innovation becomes a valuable strategy to improve the firm's competitiveness.
\end{abstract}

Keywords: Market-Driven Management; Strategic Alliances; Open Innovation; Outside-in Management; Philips Case Study

\section{Outside-in Management in Market-Driven Firms}

Global markets interdependence and hyper-competition are conditions that the firms deal with every day and impose to develop a 'philosophy of management oriented to the market' (i.e. market-driven management) in which 'customer value management' prevails, in direct and continuous confrontation with the competitors (Brondoni 2010).

As market dynamics erode the competitive advantage acquired, firms are forced to rethink their customer value creation strategies (Martens et al. 2012). Marketdriven management (Narver, Slater 1990; Kohli, Jaworski 1990) helps firms to identify and satisfy customers' needs more efficiently than competitors so to create customer value propositions that are superior to those offered by rivals. This means to deliver new value propositions looking for: higher rates of innovation, minimum costs and the best differentiation from competitors.

For that reason firms are pushed to disaggregate their business on the global market. Frequently, market-driven firms locate their activities in the convenientest geographical areas according to the market-space management logic. In fact, the

\footnotetext{
*Assistant Professor of Management, University of Milan-Bicocca (elisa.arrigo@unimib.it)
} 
market space is modified on the basis of the threats and opportunities of multiple potential locations for the different corporate activities (Brondoni 2008).

Corporate processes are dispersed across different sites; for example, manufacturing activities are often distributed across various partners and countries where the cost of raw materials and final assembling is lower. In this way, marketdriven firms expand their activities over several locations to take advantage of lower resources and labour costs but also because they recognize that leveraging knowledge and innovation developed globally has become increasingly important.

Since the companies compete in a situation of intense rivalry defined by political, social, economic and technological markets instability, they can't simply react to the competitors' moves or to the customers' requests but they must anticipate them. For this reason, market-driven firms employ an outside-in management where the corporate strategy starts with the analysis of the competitive environment.

Firms adopting an outside-in management go far beyond a simple observation of rivals and understanding of consumers' desires, they remodel the supply chain by eliminating and inserting partners depending on the conditions of the markets, or they give new tasks to actual partners in relation to the firm's requirements (Jaworsky et al. 2000; Tuominem et al. 2004).

A market-driven orientation therefore pushes firms to seek to change the market structure or the behaviour of the players so as to improve their competitiveness, looking for new sources of value for customers or growth opportunities.

On the contrary, with an inside-out management, the corporate strategy begins internally and looks outside the firm: this approach is characteristic for a situation of controlled competition (Brondoni 2005) where corporate conduct aims to preserve the existing status quo. Firms need to build and integrate their skills from a vantage point in order to be on the alert to the opportunities and threats present on the environment. Thus, the monitoring and scanning activities are crucial. However, an inside-out management limits the firm's ability to anticipate market transformations and to modify the competitive relationships system existing inside the marketplace.

In open markets, corporate decisions are driven by the analysis of current and potential customers' requests and by the competitors' conducts implemented to respond to them. It is also relevant to recognize rivals that are not competitors today but could become in the future, for example firms manufacturing or selling complementary products that can increase or reduce the demand of the firm.

Usually, market-driven firms are able to develop a global scale learning platform and, to strengthen the ability to catch insights from the outside, they must hold appropriate channels for sharing information internally (Baker, Sinkula 1999). In effect, in global markets, a sustainable competitive advantage position depends on the firm ability to obtain, integrate, reconfigure and share knowledge in a little time and better than competitors.

Market-driven firms develop specific capabilities to anticipate market modifies and to manage increased volatility and instability (Morgan et al. 2009). As argued by Day (1994), market-driven firms possess distinctive capabilities developed in three main corporate processes: the inside-out processes (as: manufacturing, logistics, technology development, human resource management, etc.); the outsidein processes (as: market sensing, customer linking, channel bonding and technology monitoring) and the spanning processes needed to integrate the inside-out and 
outside-in processes (customer service delivery, new product development, pricing, purchasing, etc.).

The outside-in capabilities allow the firm to tie with the external environment so that it can be anticipatory and responsive in satisfying the customers better and first than competitors grasping new business opportunities. Thanks to these capabilities the firm builds strong relationships with customers, distributors and suppliers.

At the same time, the distinctive capabilities allow market-driven firms to scan each zone or player of their periphery: competitors, customers, intermediaries, retailers, influencers and the macro-environment trends. The outside-in management together with a focused orientation on the competitors leads firms to two key results: first of all, having a better competitive environment's knowledge and, secondly, can make the periphery (Saka-Helmhout 2011) of the market less obscured. The analysis of every signal from the markets as new offering from competitors, latent needs of customers and, also, the institution of strategic alliances or the lobbying efforts are decisive for the corporate success.

The purpose of the present article, primarily based on business management literature review, is to examine how market-driven firms, adopting an outside-in strategy, join together in partnerships and alliances in order to manage innovation more efficiently in an open way. To this aim, a case study (Yin 1984) has been analysed; the company selected is Philips, a global technology company which invests strongly in innovation and adopts an open innovation strategy. The information used for the case study comes from academic literature review, publicly available material, the Philips website and corporate reports (2012 Philips Annual Report).

\section{Strategic Alliances and Outside-in Management}

Strategic alliances are become very popular in global markets; they can be defined as "voluntary arrangements between firms involving exchange, sharing or co-development of products technologies or services" (Gulati 1998).

In recent years there has been a growing interest in understanding why firms form strategic alliances and what factors influence their success. In the seminal work of Kogut (1988) on the joint ventures, a particular kind of strategic alliance, three main motivations, applicable also to other types of alliances, have been highlighted: the transactional costs, the enhancement of the competitive position and the acquisition of knowledge. In fact, firms inside a strategic alliance can improve their performance through several sources: scale economies, effective risk management, cost efficient market entries and, especially, learning from partners (Ireland et al., 2002).

With regards to the factors influencing the success of an alliance, the network perspective (Gulati 1999) pointed out that firms' strategic actions are affected by the social context in which they are embedded and the firm's social context is represented by the relationships with network's partners.

Kale et al. (2002) demonstrated that firms having a dedicated alliance function, with the task of supervising and organizing the firm's alliance activity, have a greater likelihood of alliance success. In a subsequent study, Kale and Singh (2007) proposed the 'alliance learning process' as the process "that involves articulation, codification, sharing, and internalization of alliance management know-how". 
Trough this process, the firms inside the alliance can learn, accumulate, and leverage knowledge from the alliance knowhow. Consequently, the alliance will benefit from the presence of multiple learning processes between the partners inside the agreement and it would reach more easily a growth.

A strategic alliance can adopt many configurations: vertical alliance (when the partners are on different phases of supply chain), horizontal alliance (among direct competitors) and cross-industry partnership (among partners operating in different industries). Cross-border strategic alliances (Hitt et al. 2005) are set up so that companies can expand into global markets more easily, leveraging their core competencies and, moreover, acquiring from the partners knowledge about the local markets. The mutual interdependence among firms inside the strategic alliance facilitates the diffusion and incorporation of local knowledge. In fact, the dissemination of corporate activities over different places and dynamic and competitive environment have made progressively more difficult for a single firm to hold and exploit all relevant resources to compete in the marketplace. As a result, many firms have undertaken plans to extend their activities on worldwide landscape, and mega-organisations with global networks are created (Brondoni 2008). Also in these organisations, knowledge management is emphasised because collaboration between the firms is achieved by the creation of specific information channels and flows inside the networks.

The network structure is more flexible and more responsive to changing market needs and information and knowledge flow across the boundaries within and outside every firm. As market knowledge circulates in multiple directions, thanks to the outside-in management, a firm can: benefit from external knowledge hailing from dispersed locations, internalize local knowledge and share it across locations. In particular, the network configuration of global firms promotes the learning from each periphery of the competitive scenario. The larger is the company, the more are the points of contact it will have with the periphery of the global markets.

This is true also for the Research and Development (R\&D) activity traditionally centralised in the head quarter of each firm. In the past, firms designed and developed their products using internal components and internal R\&D departments. Now the R\&D is spread over different international centers of technical excellence and, often, also over firms geographically distant each other. Modern technology is so complex that a single firm, even if large, cannot hold the financial resources necessary to develop a new product or process alone. Consequently, global networks are created to connect the old internal $R \& D$ departments and deal out the innovation process across the system of external partners and offshore sites.

According to an online survey conducted by the Economist Intelligence Unit (Tyrrel 2007), the key external partners in strategic partnerships for innovation are: universities (cited by $60 \%$ of respondents), customers (50\%), suppliers (47\%) and alliance partners $(43 \%)$. Firms traditionally closed to the outside, now, recognize the importance of good relationships with partners because new opportunities could be caught.

\section{R\&D Global Networks and Innovation}

R\&D offshoring is a new important trend for global companies. United States (US), one of the richest countries of the world, are the most popular destination of 
offshore R\&D. US high labour cost is compensated by a high-quality workforce and robust intellectual property protection. India, that produces one million englishspeaking graduates a year with high competences in technology, is the second destination. China is the third one for its low intellectual property protection and the legal system too faraway from the international standards (Tyrrel 2007).

$\square$ Samsung, a world leader in high-tech electronics manufacturing and digital media, responds to the highly uncertain business environment and the increasingly competitive marketplace through commitment to $R \& D$. Each year the firm invests at least $9 \%$ of its sales revenue in $R \& D$ activities. Its research and development network spreads out six Samsung centers in Korea and 18 more in nine other countries, including the United States, the United Kingdom, Russia, Israel, India, Japan and China, as well as other research centers and universities. Closely linked, these centers are tasked with hiring top-notch local talent, investigating the latest local technology trends, and bringing to life those technologies that offer the greatest benefits (Samsung website).

In the last years, the governments of countries like India and China imposed on western firms to manufacture locally in order to sell their products there. Doing so, these countries have built specific R\&D capabilities and now represent an actractive destination for off-shore $R \& D$ for the potential country-specific advantages accessible to global companies.

The advantages deriving from a global network's partnership for innovation are many: first of all, each firm utilizes the internal relationships and network to complement its knowledge so to innovate more efficiently. Besides, the firms belonging to global networks benefit also of: cost savings (because the R\&D costs can be shared by various partners); better access to specialist skills (each firm could have a specialization to manage specific situations or problems); knowledge and insights into local markets, and faster time to market (Tyrrel 2007).

At the same time, firms engaged in global networks for innovation must balance the need to promote openness among partners while taking proactive steps to protect their core competences (Muller et al. 2012). In fact, inside the alliance, firms participating must share the control and management of the collaborative competitive relationships. When a firm is linked to other firms within a global network it is more likely to have detailed information about each other and to know new projects; so having access to multiple collaborations can promote both innovative and imitative processes.

As shown in the Figure 1, the most significant risks associated to the firm's presence in a global partnership for innovation are the preservation of the intellectual property and the loss of control over innovation process.

In fact, companies can leverage external partners to fill their lacks but at once they become more vulnerable. This is true, in particular, in horizontal alliances where simultaneous cooperation and competition between partners add complexity to the network's management (Ireland et al. 2002). Often the success of an innovative firm stimulates other firms to reproduce a similar process or product, or to make some changes to the original concept with the aim of creating new applications to meet the needs of new customers or new markets. In that latter case, 
the firm puts into practice an imitative process, i.e. it implements something new for the firm but already known by others firms or by the market (Zhou 2006).

The management of the intellectual property sharing is a key question because exposing too much information may cause loss of control over important sources of competitive advantage and disclosing information and knowledge can promote external innovation (Perks, Jeffery 2006). In order to prevent such risk, clear intellectual property guidelines and expected two ways information flows need to be specified inside the partnership as well as some exclusive rights for specific firms to any intellectual property discoveries. Especially firms that are engaged in strategic alliances with competitors have to define formal methods (mainly patents and copyrights) to protect their competitive advantages while they absorb knowledge from the outside.

Figure 1: Risks in Developing Global Innovation Networks

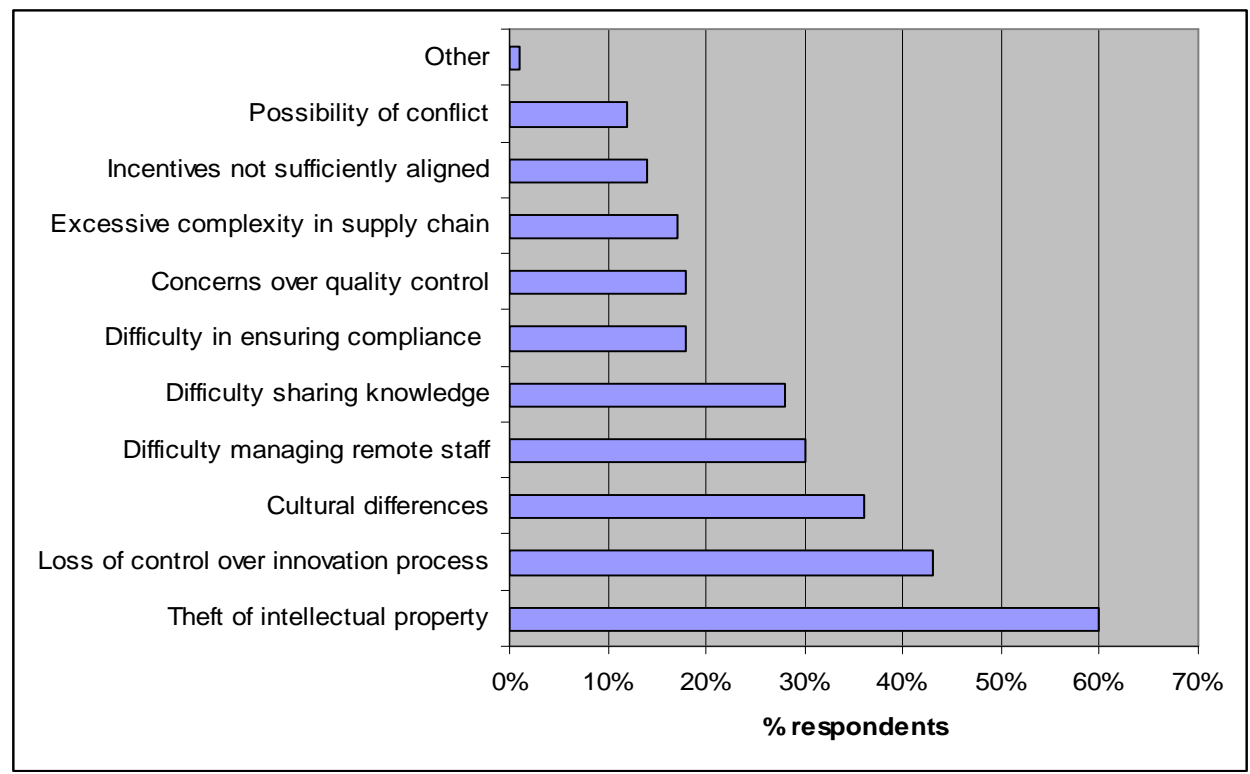

Source: P. Tyrrel, Sharing the Idea. The Emergence of Global Innovation Networks, The Economist Intelligence Unit (2007).

\section{Open Innovation and Outside-in Management}

Innovation is crucial for attaining a competitive advantage over the competitors (Baker, Sinkula 1999; Gassmann, Enkel 2010; Hurley, Hult 1998; Knight, Cavusgil 2004; Zhou 2006) and its notion underlines the dynamic aspect of novelty that improves the firm's competitive position. An innovation involves many phases whereby firms transform ideas into new or improved products, services or processes.

Firm's growth is strictly linked to the ability of innovating new value for current customers and attracting new customers. The pressure for customer value innovation should be relatively straightforward for market-driven firms who hold a superior market knowledge on how customers are changing and what competitors are doing. 
Market-driven firms exploit an innovative capacity (Lisboa et al. 2011) to keep all the sources of innovation under control as well as those implemented by the rivals. In fact, controlling innovation from a strategic point of view means a continuous monitoring of the innovations introduced by the rivals and entails assessing the results in terms of value for customers.

Firms with greater capacity to innovate will be more successful in responding to environmental trends and in developing new capabilities that lead to competitive advantage (Hurley, Hult 1998). Market-driven firms possess a specific innovation management capability (Arrigo 2010) based: first of all, on an outside-in management to catch new opportunities on the markets; and, secondly, on a synergistic information distribution system and accessible memories in order to catalogue what has worked in the past.

The aptitude to run innovative processes effectively stems from a firm's ability to exploit the wealth of information, generating learning and new knowledge. Nowadays, very frequently, innovative processes or products derive from the corporate ability to position the receptive points in strategic places of global markets so to capture new insights with an outside-in approach.

In particular, the outside-in management guides the creation of value in marketdriven firms through two innovative capabilities such: exploration and exploitation (March 1991). In fact, firms are focused on these two kinds of activities: the pursuit of new knowledge and the use of current knowledge. More precisely, exploration concerns to the firm's search for discoveries and experimentations so to find new business options, new products or new relationships with partners in new markets. Exploitation, instead, refers to the use of the current knowledge, resources and capabilities for the understanding of existing markets, products or processes, and for improving the active relationships with customers, competitors and partners so to maintain the competitive position acquired (Aspara et al. 2011). Thus, the degree of 'newness' will be the principal condition that distinguishes exploration of transferred knowledge from its exploitation (Bierly et al. 2009).

As argued by Levinthal and March (1993), firms must maintain a balance between exploitation and exploration but this is quite complex because the learning activity leads firms to dynamic processes of knowledge management and consequently can contribute both positively and negatively to the corporate competitiveness.

Usually exploitation produces more understandable, earlier and closer feedback than exploration since it is able to correct itself sooner; so in order to obtain the best mix of exploration and exploitation, market-driven firms must rapidly learn from their experience and at the same time from the competitors one.

Thanks to both exploitation and exploration firms are able to recombine skills and knowledge creating new innovative processes. A study accomplished on the Japanese global networks for innovation illustrates that horizontal alliances are more likely to make easy the process of knowledge exploration among partner firms, through a broad combinations of knowledge so to find new solutions in terms of products or processes. On the contrary, vertical networks facilitate the process of intensified knowledge exploitation among partner firms, through the integration and coordination of interdependent technologies (Zhang 2011).

Inside the global network's alliances, market-driven firms share resources and knowledge and can learn from their competitors. Some authors coined the expression Inter-Firm Market-Orientation (IMO) to indicate "the ability of a firm 
to learn about markets through their collaboration with partners" (Cambra-Fierro et al. 2011, p. 449). As a matter of fact, market-driven firms tend to expand their innovation potential being open to the outside and the search activity is based on a continuous interaction with stakeholders.

Collaborating with partners, customers, competitors or suppliers are now well recognized as an essential factor able to enhance firms' performance and innovativeness (Von Hippel 1986). Market-driven firms, implementing an outsidein management, embrace the idea of treating innovation in an open way. Indeed, the open innovation expressly refers to the use of inflows and outflows of knowledge among many partners to accelerate internal innovation (Chesbrough 2003).

Gassmann and Enkel (2004) identify three core processes of open innovation: outside-in, inside-out and coupled. The outside-in process refers to the activities in which companies monitor the environment to source knowledge and technologies from stakeholders (consumers, suppliers, etc.) and to license intellectual property from other firms. The inside-out process includes technology transfers by the commercialization of in-house technology. The coupled process combines outsidein and inside-out processes by working together with complementary partners or by participating in other companies. All these processes complement one another but the outside-in process is the prevalent.

Open innovation emphasizes the importance of capturing knowledge from the external environment and converting it into innovative processes, products or services. Customers pay increased attention to product attributes and many commercially relevant products were initially conceptualized by lead users rather than manufacturers. At the same time, every firm needs to pay attention and maintain good relationships with partners to enhance its own competitive ability. The partners within the supply chain are one of the most important sources of knowledge applied to develop innovative processes and the combination of the company know-how with these of suppliers, customers and external actors can increase the firm's innovativeness (Inauen, Schenker-Wicki 2011).

Also cooperation with competitors can represent an other way to acquire knowledge; in fact, market-driven firms possess an absorptive capability (Cohen, Levinthal 1990) that facilitates learning from others firms and accelerates the implementation of new processes. Successful examples of 'cross-industry innovation' and technological spillovers from other industries, may be represented by Bmw's Drive System that was transferred from the game industry or Nike's shock absorbers that were adapted from Formula One racing technology (Gassmann, Enkel 2010).

A recent study (Inauen, Schenker-Wicki 2011) accomplished on data set of 141 stock-listed firms shows that firms with a higher openness towards customers are more likely to increase their product innovations; instead, the more the cooperation with suppliers, competitors and partners, the more process innovation will be.

\section{The Philips Case}

Philips was founded in Eindhoven in 1891 by Frederik and Gerard Philips to manufacture incandescent lamps and other electrical products. Today, it is one of the global largest technology companies with sales of euro 24,7 billions in 2012 . The company has 118 millions of employees and operates in 100 countries in three 
main business areas: healthcare, lighting and consumer well-being (Philips 2012 Annual Report).

Philips's mission is "to improve people's lives through meaningful innovation" and the vision is "to make the world healthier and more sustainable through innovation". Consequently, innovation is in everything the company does and, in fact, a good part of the company's sales are invested in research and development; in 2012 the R\&D expenses amounted to euro 1,8 billions (equal to the 7,3\% of sales).

Until the end of the 1980s, the R\&D management changed considerably with a stronger division of labor between the research labs, the institution of centers of excellence, the adoption of formal decision making processes and the integration of the globally dispersed laboratories. Largely, these transformations were due to the growing competition in electronics and to the Philips limited knowledge resources.

The strong competition pushed the firm to adopt a market orientation with a focus on competencies and the lack of resources pressed toward the delocalization of $R \& D$ and production. The R\&D was decentralized in a number of divisions dispersed worldwide and the Philips research was reorganized into a network of specialized centers of excellence (CoE) (Reger 2004).

Today, pursuing an open innovation strategy, the company shares its expertise and technical abilities with many partners with the aim of creating win-win propositions. Philips works with potential strategic partners, suppliers of its business and with firms providing a broader vision on the global market. Trough "inside-out innovation", the firm makes some of its skills and competences available to the outside world and, through "outside-in innovation", it draws on the capacities of the strategic partners so to gain new insights and to access new technologies (Philips website). The Philips Group Innovation (PGI), availing of 4800 professionals, has been created to encompass: Philips research, Philips intellectual property \& Standard, Philips innovation services, the Philips innovation campus, Philips design and the emerging business areas. Also PGI participates in open innovation trough relationships with academics and industrial partners.

There are three main research programs in Philips:

- Healthcare: the research healthcare program develops innovative solutions for a sustainable healthcare system focused on: diagnostic imaging, imageguided intervention \& therapy, patient care, clinical decision support, home and personal healthcare, healing environments and services.

- Lifestyle: Philips wants to improve customers well-being with research programs focused on healthy life, personal care, home living and interactive living.

- Lighting: as the 19\% of global electricity consumption is used for lighting, Philips looks for new and sustainable solutions for the lighting systems linked to the LED conversion and system, advanced light delivery, light and energy management.

The $R \& D$ is performed worldwide in both mature and emerging markets; the headquarter is located in Eindhoven (Netherlands), the Philips powerful hub, and other research facilities are in France, Germany, United Kingdom, India, USA and China. In this way, the company, by an outside-in approach, can deliver innovations that address local market needs.

Philips has six important R\&D centers, each one with particular specializations.

- Philips Research Eindhoven (HQ) (The Netherlands) 
The center (at that time, named Philips High Tech Campus) was created in 1998 by the firm as a single location where to concentrate all its $R \& D$ activities. Knowledge sharing and mutual inspiration generated an increase in the innovative capacity of the company. In order to improve this process, some years later, Philips decided to open the Campus to other high-tech companies. The center renamed in High Tech Campus Eindhoven and became one of the best centers of high-tech industries, with 8.000 scientists and employees and more than 100 companies over 60 nationalities.

\section{- Philips Research Bangalore (India)}

Bangalore is considered the India's Silicon Valley, one of the principal hub for IT/electronics developments. In this center, $80 \%$ of the research is on healthcare (with solutions for cardiology, prenatal care and oncology screening), and the $20 \%$ on energy (photovoltaic solutions). Here, Philips works with well-known research institutes, universities and hospitals for clinical collaborations.

\section{- Philips Research Briarcliff (North America)}

The center is situated in the Boston-New York-Washington corridor which is highly populated by pharmaceutical, biomedical technology and healthcare companies so to leverage the innovation ecosystem created. The main partners are governmental organizations (as the National Institutes of Health) and universities (the Columbia, Yale and John Hopkins Universities)

- Philips Research Cambridge (United Kingdom)

The Philips center is in the Cambridge innovation hub with more than 40,000 employees in the high tech industry. The main research topics include home healthcare solutions, location technologies and microbiology. The company collaborates with 80 partners from the university world and the multinationals one.

- Philips Research Hamburg (Germany)

This center represents an excellent structure for the medical sector; physicians, engineers and mathematicians work together to research in different areas of healthcare. Philips has built a relationships network with clinical sites, scientific institutions and external industrial partners.

- Philips Research Shanghai (China)

In Shanghai, the company created a consumer centric research organization where young researchers search for new solutions in the three business areas: Healthcare, Lighting, and Consumer Lifestyle.

In all these centers, Philips cooperates with many partners from different countries and different sectors, shares its knowledge with them and pursues to manage innovation with an open approach. In this way, the firm has hold a global leadership position in the healthcare, lighting and consumer life-style sectors.

\section{Conclusions}

Looking at strategic alliances beyond firms' boundaries for innovation projects to share risks, costs and expertise is a major trend in innovation management discussions. Frequently, firms create global networks to increase their innovativeness and, thanks to an outside-in management, they can absorb, more easily, external knowledge about new products or processes.

In particular, the network configuration consents to identify and utilize all the available channels of potential learning: supply chain channels, distribution and 
marketing channels, production channels, etc. In that way, firms inside the network can recognize where to source the best raw materials and the key components, the most advanced technology, if there are government supports, which is the best distribution system or the greatest product feature, etc. Strategic networks help firms to cope with turbulent environments, reducing their dependence on resources outside of their control and successfully reposition themselves in global markets.

Within the global network partnership, as shown in the Philips case, open innovation becomes one of the best approaches to draw knowledge insights from external partners trough a better interaction with suppliers, universities, competitors, customers, etc. In so doing, market-driven firms are able to quickly recognize market opportunities, respond to customers' desires and deliver a variety of products technologically advanced at a lower cost.

\section{Bibliography}

Arrigo Elisa (2010) Innovation and Market-Driven Management in Fast Fashion Companies, Symphonya. Emerging Issues in Management (symphonya.unimib.it), n. 2, pp. 67-85.

http://dx.doi.org/10.4468/2010.2.06arrigo

Aspara Jaakko (2011) Tikkanen Henrikki, Pontiskoski Erik, Jarvensivu Paavo, Exploration and Exploitation across Three Resources Classes, European Journal of Marketing, vol. 45, n. 4, pp. 596-630.

http://dx.doi.org/10.1108/03090561111111352

Baker William E., Sinkula James M. (1999) Learning Orientation, Market Orientation, and Innovation: Integrating and Extending Models of Organizational Performance, Journal of MarketFocused Management, vol. 4, n. 4, pp. 295-308.

http://dx.doi.org/10.1023/A:1009830402395

Bierly Paul E., Damanpour Fariborz, Santoro Michael D. (2009) The Application of External Knowledge: Organizational Conditions for Exploration and Exploitation, Journal of Management Studies, vol. 46, n. 3, pp. 481-509.

http://dx.doi.org/10.1111/j.1467-6486.2009.00829.x

Brondoni Silvio M. (2010) Intangibles, Global Network and Corporate Social Responsibility, Symphonya. Emerging Issues in Management (symphonya.unimib.it), n. 2, pp. 6-24.

http://dx.doi.org/10.4468/2010.2.02brondoni

Brondoni Silvio M. (2008) Market-Driven Management, Competitive Space and Global Network, Symphonya. Emerging Issues in Management (symphonya.unimib.it), n. 1, pp. 14-27. http://dx.doi.org/10.4468/2008.1.02brondoni

Brondoni Silvio M. (2005) Ouverture de 'Over-Supply and Global Markets - 1', Symphonya. Emerging Issues in Management (symphonya.unimib.it), n. 1, pp. 1-13. http://dx.doi.org/10.4468/2005.1.01ouverture

Cambra-Fierro Jesus J., Hart Susan, Fuster Mur Ana, Polo Redondo Yolanda (2011) Looking for Performance: How Innovation and Strategy May Affect Market Orientation Models, Innovation: Management, Policy \& Practice, vol. 13, n. 2, pp. 154-172.

http://dx.doi.org/10.5172/impp.2011.13.2.154

Chesbrough Henry (2003) The Logic of Open Innovation: Managing Intellectual Property, California Management Review, vol. 45, n. 3, pp. 33-58.

http://dx.doi.org/10.2307/41166175

Cohen Wesley M., Levinthal Daniel A. (1990) Absorptive Capacity: a New Perspective on Learning and Innovation, Administrative Science Quarterly, vol. 35, n. 1, pp. 128-152.

http://dx.doi.org/10.2307/2393553 
Day George M. (1994) The Capabilities of Market-Driven Organizations, Journal of Marketing, Vol. 58, pp. 37-52.

http://dx.doi.org/10.2307/1251915

Day George S., Schoemaker Paul J.H., (2007) Seeing Sooner, Marketing Management, vol. 16, n. 6, pp. 20-27.

Enkel Ellen, Gassmann Oliver (2010) Creative Imitation: Exploring the Case of Cross-Industry Innovation, $R \& D$ Management, vol. 40, n. 3, pp. 256-270.

http://dx.doi.org/10.1111/j.1467-9310.2010.00591.x

Gassmann Oliver, Enkel Ellen, Chesbrough Henry (2010) The Future of Open Innovation, $R \& D$ Management, vol. 40, n. 3, pp. 213-221.

http://dx.doi.org/10.1111/j.1467-9310.2010.00605.x

Gassmann Oliver, Enkel Ellen (2004) Towards a Theory of Open Innovation: Three Core Process Archetypes, Proceedings of the R\&D Management Conference, Lisbon, Portugal, July 6-9.

Gulati Ranjay (1998) Alliances and Networks, Strategic Management Journal, vol. 19, n. 4, pp. 293-317.

Hitt Michael A., Ireland R. Duane, Hoskinsson Robert E. (2005) Strategic Management: Competitiveness and Globalization, South Western College, Cincinati.

Huang Ju-Yu, Chou Tzu-Chuan, Lee Gwo-Guang (2010) Imitative Innovation Strategies. Understanding Resources Management of Competent Followers, Management Decision, vol. 48, n. 6, pp. 952-975.

http://dx.doi.org/10.1108/00251741011053488

Hurley Robert F., Hult Tomas M. (1998) Innovation, Market Orientation and Organizational Learning: an Integration and Empirical Examination, Journal of Marketing, vol. 62, pp. 42-54. http://dx.doi.org/10.2307\%2F1251742

Inauen Matthias, Schenker-Wicki Andrea (2011) The Impact of Outside-in Open Innovation on Innovation Performance, European Journal of Innovation Management, vol. 14, n. 4, pp. 496-520. http://dx.doi.org/10.1108/14601061111174934

Ireland R. Duane, Hitt Michael A., Vaidyanath Deepa (2002) Alliance Management as a Source of Competitive Advantage, Journal of Management, vol. 28, n. 3, pp. 413-446.

http://dx.doi.org/10.1177/014920630202800308

Jaworski Bernard J., Kohli K. Ajay, Sahay Arvin (2000) Market-Driven versus Driving Markets, Journal of the Academy of Marketing Science, vol. 28, n. 1, pp. 45-54.

http://dx.doi.org/10.1177/0092070300281005

Kale Prashant, Dyer J., Singh Harbir (2002) Alliance Capability, Stock Market Response, and Long Term Alliance Success: the Role of the Alliance Function, Strategic Management Journal, vol. 21, n. 8, pp. 747-768.

http://dx.doi.org/10.1002\%2Fsmj.248

Kale Prashant, Singh Harbir (2007) Building Firm Capabilities through Learning: the Role of the Alliance Learning Process in Alliance Capability and Firm-Level Alliance Success, Strategic Management Journal, vol. 28, pp. 981-1000.

http://dx.doi.org/10.1002/smj.616

Knight Gary A., Cavusgil S Tamar (2004) Innovation, Organizational Capabilities, and the BornGlobal Firm, Journal of International Business Studies, n. 35, pp. 124-141.

http://dx.doi.org/10.1057\%2Fpalgrave.jibs.8400071

Kogut Bruce (1998) The Stability of Joint Ventures: Reciprocity and Competitive Rivalry, Journal of Industrial Economics, n. 38, pp. 183-198.

Kohli Ajay K., Jaworski Bernard J. (1990) Market Orientation: The Construct, Research Propositions, and Managerial Implications, Journal of Marketing, April, pp. 1-18. http://dx.doi.org/10.2307/1251866

Levinthal Daniel A., March James G. (1993) The Myopia of Learning, Strategic Management Journal, vol. 14, n. S2, pp. 95-112. 
http://dx.doi.org/10.1002\%2Fsmj.4250141009

Lisboa Ana, Skarmeas Dionysis, Lages Carmen (2011) Innovative Capabilities: their Drivers and Effects on Current and Future Performance, Journal of Business Research, vol. 64, pp. 1157-1161. http://dx.doi.org/10.1016\%2Fj.jbusres.2011.06.015

March James G. (1991) Exploration and Exploitation in Organizational Learning, Organization Science, vol. 2, n. 1, pp. 71-87.

http://dx.doi.org/10.1287\%2Forsc.2.1.71

Martens Rudy, Matthyssens Paul, Vandenbempt Koen (2012) Market Strategy Renewal as a Dynamic Incremental Process, Journal of Business Research, vol. 65, n. 6, pp. 720-728.

http://dx.doi.org/10.1016\%2Fj.jbusres.2010.12.008

Morgan Neil A., Vorhies Douglas W., Mason Charlotte H. (2009) Market Orientation, Marketing Capabilities and Firm Performance, Strategic Management Journal, vol. 30, n. 8, pp. 909-920. http://dx.doi.org/10.1002\%2Fsmj.764

Muller Amy, Hutchins Nate, Cardoso Pinto Miguel (2012) Applying Open Innovation where Your Company Needs it Most, Strategy and Leadership, vol. 40, n. 2, pp. 35-42. http://dx.doi.org/10.1208/10878571211209332

Narver John C., Slater Stanley F. (1990) The Effect of a Market Orientation on Business Profitability, Journal of Marketing, October, pp. 20-35.

http://dx.doi.org/10.2307/1251757

Perks Helen, Jeffery Richard (2006) Global Network Configuration for Innovation: a Study of International Fibre Innovation, $R \& D$ Management, vol. 36, n. 1, pp. 67-83.

http://dx.doi.org/10.1111/j.1467-9310.2005.00416.x

Philips Annual Report, 2012.

Reger Guido (2004) Coordinating Globally Dispersed Research Centres of Excellence - The Case of Philips Electronics, Journal of International Management, vol. 10, pp. 51-76. http://dx.doi.org/10.1016/j.intman.2003.12.004

Saka-Helmhout Ayse (2011) Learning from the Periphery: beyond the Transnational Model, Critical Perspective on International Business, vol. 7, n. 1, pp. 48-65. http://dx.doi.org/10.1108\%2F17422041111103831

Tuominen Matti, Rajala Arto, Mo“ller Kristian (2004) Market-Driving versus Market-Driven: Divergent Roles of Market Orientation Business Relationships, Industrial Marketing Management, vol. 33, n. 3, pp. 207-217.

http://dx.doi.org/10.1016/j.indmarman.2003.10.010

Tyrrell Paul (2007) Sharing the Idea. The Emergence of Global Innovation Networks, The Economist Intelligence Unit, 2007.

Von Hippel Eric (1986) Lead Users: A Source of Novel Products, Management Science, vol. 32, n. 7, pp. 791-805.

http://dx.doi.org/10.1287/mnsc.32.7.791

Yin Robert K. (1984) Case Study Research - Design And Methods, Sage Publications, Beverly Hills.

Zhang Yanli, Cantwell John (2011) Exploration and Exploitation: The Different Impacts of Two Types of Japanese Business Group Network on Firm Innovation and Global Learning, Asian Business \& Management, vol. 10, n. 2, pp. 151-181.

http://dx.doi.org/10.1057/abm.2011.7

Zhou Kevin Zheng, Brown James R., Dev Chekitan S., Agarwal Sanjeev (2007) The Effects of Customer and Competitor Orientations on Performance in Global Markets: a Contingency Analysis, Journal of International Business Studies, vol. 38, pp. 303-319.

http://dx.doi.org/10.1057\%2Fpalgrave.jibs. 8400259

Zhou Kevin Zheng (2006) Innovation, Imitation, and New Product Performance: The Case of China, Industrial Marketing Management, n. 35, pp. 394-402. 